\title{
Riverbed-material texture and composition of Bishnumati River, Kathmandu, Nepal; implications in provenance analysis
}

\author{
Naresh Kazi Tamrakar \\ Central Department of Geology, Tribhuvan University, Kathmandu, Nepal
}

\begin{abstract}
The Bishnumati River, a major tributary of the Bagmati River in the Kathmandu Basin, is a low-gradient, low-sinuosity river with a short high-gradient head. The tributaries contributing the Bishnumati River supply sediments from granite-gneiss sources located towards the north of the river area, and from sedimentary rocks of the Phulchoki Group from the northwest and the west of the Bishnumati watershed. Four representative segments each from third, fourth, fifth and sixth order stretches were sampled and analysed for riverbed-material size, and gravel shape and composition, to characterise riverbed materials, to understand downstream distribution of shape, size and composition of sediments, and to understand provenance of riverbed materials.

The $\mathrm{D}_{50}$ of the segments $1,2,3$ and 4 are $25.11 \mathrm{~mm}, 0.871 \mathrm{~mm}, 3.75 \mathrm{~mm}$ and $27.86 \mathrm{~mm}$, respectively. The riverbed materials are classified as Gravel, muddy sandy Gravel and muddy Gravel, which are very poorly sorted indicating textural immaturity. Gravels are compact bladed in form. Oblate prolate index (OPI) shows more oblate nature of gravels from downstream segments (sixth order stream). Gravels have high settling sphericity (0.6-0.8) and slightly higher flatness index (0.51-0.54). They are subrounded to rounded although there exist some angular to well rounded gravels. Downstream changes in shape parameters are not remarkable perhaps because of short distance of transport, insufficient abrasion, or durability of gneissic and granitic clasts, or quick transport of gravels during floods. Shape also seems to be influenced more by inherited properties of parent rocks.

The gravels from sedimentary rocks increase from the upstream to downstream sites of the river at the expense of reduction of gneissic and granitic gravels. Existence of siltstone and sandstone gravels in the fifth (Segment 2) and forth order (Segment 3 ) mainstreams is remarkable as there is no primary parent source upstream of these segments. Existence of sedimentary gravels shows local provenance (fluvio-deltaic terrace deposits) and perhaps suggests existence of paleodrainage system different from the present
\end{abstract}

\section{INTRODUCTION}

The Bishnumati River is one of the major tributaries of the Bagmati River in the Kathmandu Basin (Fig.1). The former supplies water and sediments from the northwest region of the basin. The Bishnumati River extends for about $18.4 \mathrm{~km}$ and is a sixth order stream. First to sixth order main segments extending from Bishnumatigau to Teku have lengths $0.19,0.92,2.32,8.03,0.77$, and 6.17 $\mathrm{km}$, respectively. The river receives contributions from the Shivapuri range (Sheopuri Injection Gneiss Zone; Ohta 1973), Nagarjun range (Phulchoki Group; Stöcklin, 1980) and fluviolacustrine terraces.

Author's E-mail address: ntamrakar@hotmail.com
Tributaries such as the Lupan Khola, the Sanla Khola and the Mahadev Khola supply debris from the Shivapuri range composed of the Sheopuri Injection Gneiss Zone. One of the tributaries of the Mahadev Khola, i.e., the Sheshmati Khola supplies debris from both gneissic zone and the Phulchoki Group. Other major tributaries as the Bhaucha Khusi and the Manamati River supply debris from the Nagarjun range of the Phulchoki Group.

The Bishnumati River is a perenial stream fed by storm flow and springs. The maximum monthly discharge reaches highest $\left(3.4 \mathrm{~m}^{3} / \mathrm{s}\right)$ in August and is least $\left(0.024 \mathrm{~m}^{3} / \mathrm{s}\right)$ in February according to the data of DHM (1998). The total drainage area of the Bishnumati watershed is $102.09 \mathrm{~km}^{2}$.

The river profile is concave up (Fig. 2) with slope 


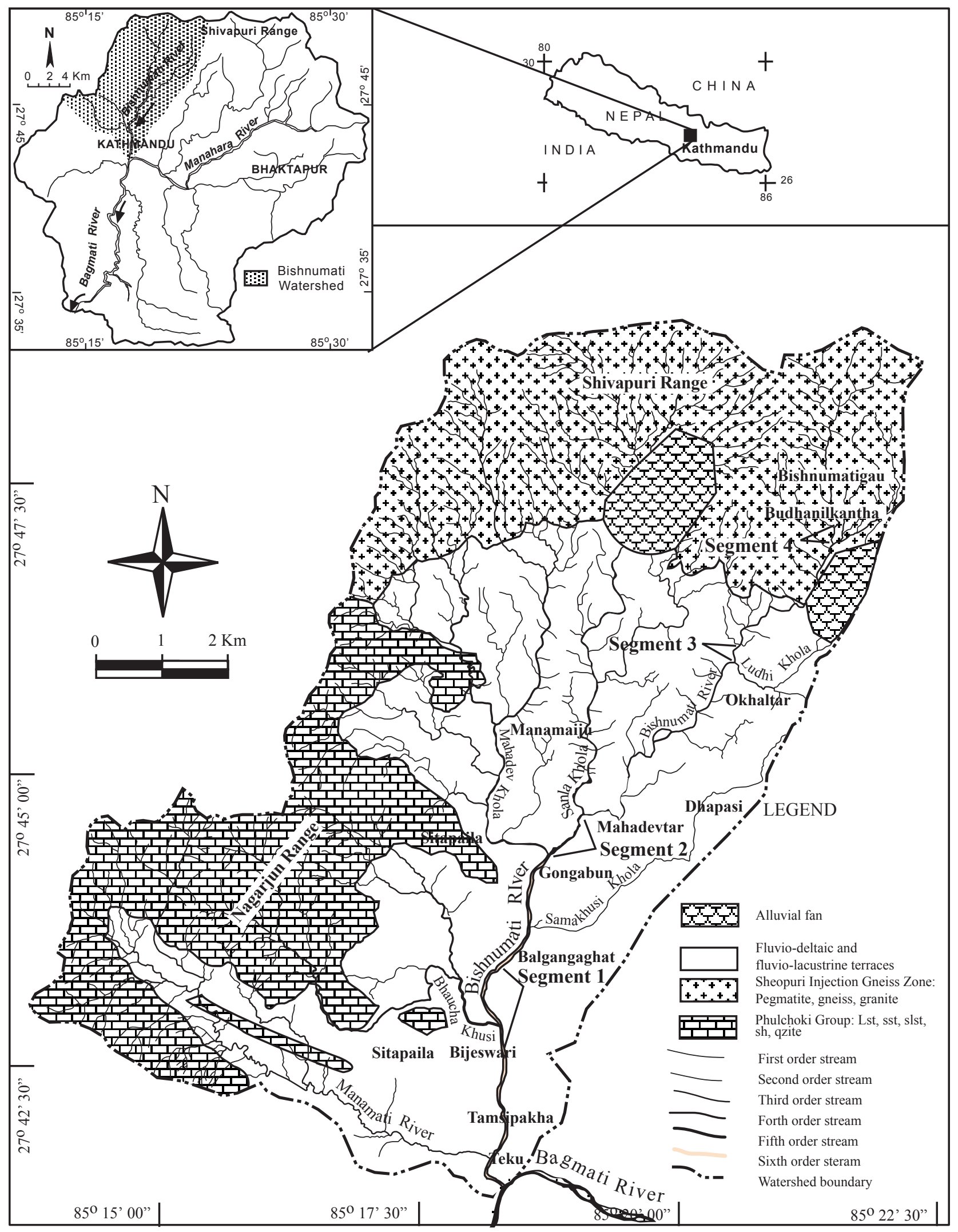

Fig. 1 Location map of study segments and stream orders of the Bishnumati Watershed 


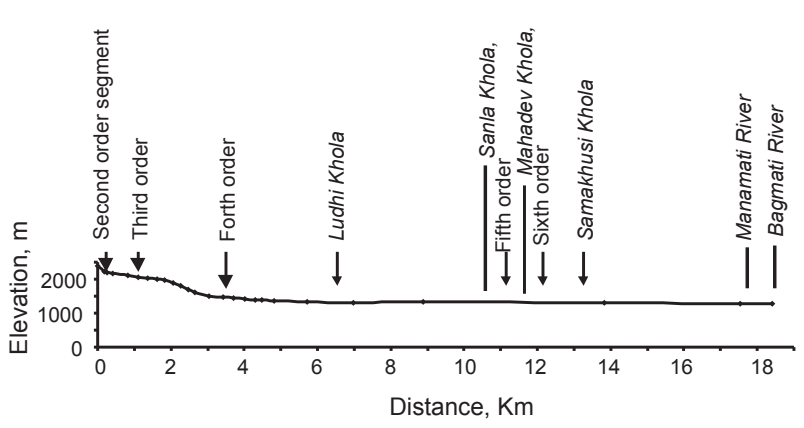

Fig. 2 Profile of the Bishnumati River

of $0.133 \mathrm{~m} / \mathrm{m}$ at third order stream and $0.004 \mathrm{~m} / \mathrm{m}$ at the rest of the mainstreams (Table 1), thus showing high gradient head and long low-gradient tail. The river appears sinuous with few side and mid bars.

The present study intends to characterise size, shape and composition of gravels measured from riverbed materials of the Bishnumati river at four different segments from downstream to upstream portions, i.e., Segment 1 (sixth order segment at Tamsipakha), Segment 2 (fifth order segment at Mahadevtar), Segment 3 (fourth order segment at Okhaltar) and Segment 4 (third order segment at Bishnumatigau). Segments 1, 2, 3 and 4 were classified according to Rosgen's (1994) scheme as F4-, F5-, C4-, and A4-type streams, respectively by Tamrakar (2004). All these rivers are of degrading nature (Adhikari and Tamrakar 2006).

The parameters of river patterns as shown in Table 1 indicate that mean meander wavelengths of Segment $1(998 \mathrm{~m})$ is far greater than rest of the other segments. Mean belt width ranges from 160 to $800 \mathrm{~m}$ showing that Segment 1 is widest and Segment 2 is narrowest. Mean radius of curvature is highest in Segment 1 but is least in Segment 4. Sinuosity ranges from 1.15 to 1.34. Segment 3 is more sinuous than other three segments (Table 1), but all these segments have value below 1.5 and therefore the Bishnumati River is a low-sinuosity river.

The study describes texture and composition of the riverbed material of the high-gradient short headed and low-gradient sinuous river. The size characterises compentence of river and is useful in stream classification, whereas composition and shape data provides information on provenance or source of
Table 1 Morphologic parameters of the Bishnumati River

\begin{tabular}{|c|c|c|c|c|}
\hline \multirow{2}{*}{$\begin{array}{l}\text { Morphologic } \\
\text { Parameters }\end{array}$} & \multicolumn{2}{|c|}{ Segment 4 Segment } & \multirow{2}{*}{$\frac{\text { Segment }}{\text { Mean }}$} & \multirow{2}{*}{$\frac{\text { Segment } 1}{\text { Mean }}$} \\
\hline & Mean & Mean & & \\
\hline Meander wavelength, $\mathrm{L}_{\mathrm{m}}(\mathrm{m})$ & 167 & 100 & 235 & 998 \\
\hline Belth width, $\mathrm{W}_{\mathrm{blt}}(\mathrm{m})$ & 170 & 540 & 160 & 800 \\
\hline Radius of curvature, $R_{c}$ & 29 & 89 & 51.4 & 465 \\
\hline Length of thalweg, $\mathrm{L}_{\mathrm{th}}(\mathrm{m})$ & 2270 & 7950 & 890 & 6170 \\
\hline Length of valley, $\mathrm{L}_{\mathrm{v}}(\mathrm{m})$ & 1980 & 5930 & 770 & 5360 \\
\hline Sinuosity, $\mathrm{K}=\mathrm{L}_{\mathrm{th}} / \mathrm{L}_{\mathrm{v}}(\mathrm{m} / \mathrm{m})$ & 1.15 & 1.34 & 1.16 & 1.15 \\
\hline Slope, $\mathrm{S}=\Delta$ Elv. $/ \mathrm{L}_{\text {th }}(\mathrm{m} / \mathrm{m})$ & 0.133 & 0.008 & 0.004 & 0.005 \\
\hline W/D ratio & 11 & 12 & 26 & 21 \\
\hline Entrenchment ratio $=\mathrm{W}_{\mathrm{fpa}} / \mathrm{W}_{\mathrm{bkf}}$ & 1.28 & 4.78 & 1.37 & 1.30 \\
\hline River segment type* & A4 & $\mathrm{C} 4$ & F5 & F4 \\
\hline
\end{tabular}

* According to Rosgen's (1994) stream classification scheme

sediments derived to the river. The size and shape data may be useful for hydraulic engineers, ecologists, and those associated with river restoration projects.

\section{METHODS}

Ten transactions in each of four segments of the Bishnumati River were traversed to obtain about 400 particles per segment of size ranging from clay to gravel according to modified Wolman's (1954) pebble counting method. Both riffle and pools were included in the traverse. For measuring particle size, template of 1 phi intervals was used. When size exceeded 180 $\mathrm{mm}$, then a measuring tape was used to determine size of particles. All the size measured are equivalent to intermediate size or sieve diameter.

Shape analysis of gravels was made by measuring axes for form indices (axial ratios and oblate-prolate index (OPI)) and settling sphericity $\left(\Psi_{\mathrm{p}}\right)$, and comparing with the comparator for roundness $(\rho)$ evaluation. Settling sphericity was calculated using axial data (Sneed and Folk 1958):

$$
\Psi_{\mathrm{p}}=\left(\mathrm{c}^{2} / \mathrm{ab}\right)^{1 / 3}
$$

where, $\mathrm{a}=$ longest axis, $\mathrm{b}=$ intermediate axis and $\mathrm{c}=$ shortest axis. Oblate-prolate index was calculated as (Sneed and Folk 1958):

$$
\text { OPI }=[\{\{(a-b) /(a-c)\}-0.5\} /\{c / a\}] \times 10
$$

For estimating roundness-value of Folk (1955), Power's (1953) roundness chart was used. Besides shape parameters, individual gravel was also analysed for composition. 


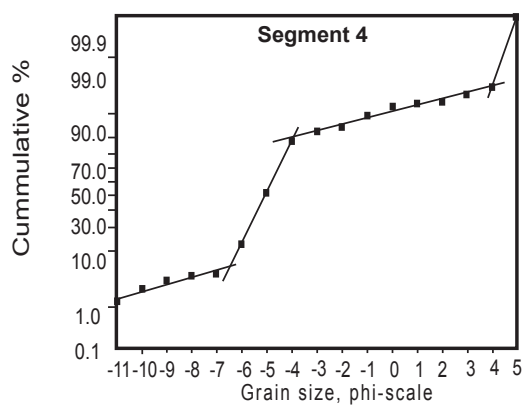

(a)

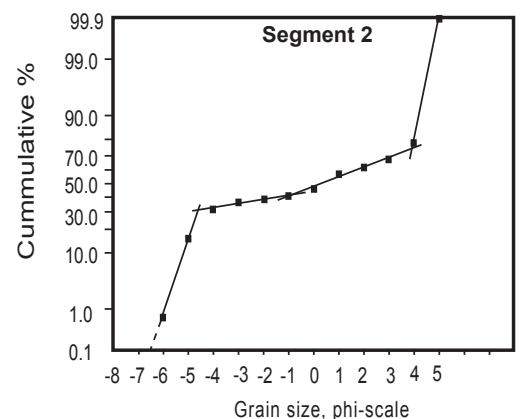

(c)

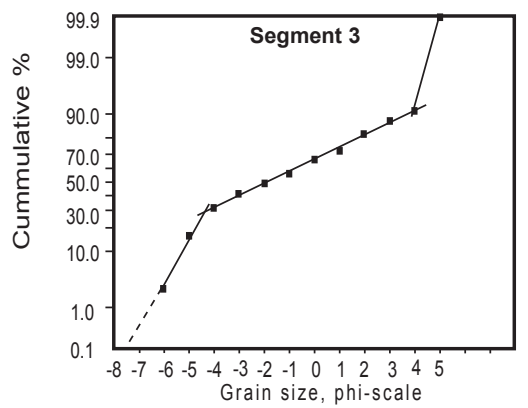

(b)

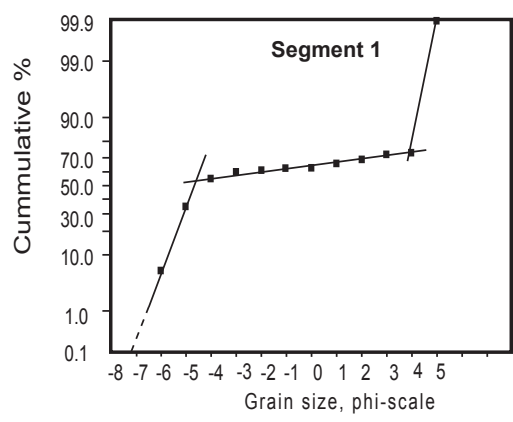

(d)

Fig. 3 Grain size distribution of riverbed materials: (a) Segment 4, (b) Segment 3, (c) Segment 2 and (d) Segment 1.

\section{RESULTS}

\section{Particle size distribution}

Cumulative frequency percent of particle size distribution of each of four segments versus phi sizes are plotted and shown in Fig. 3. Substrate samples of Segments 1, 2 and 3 were devoid of boulder. However, clay to cobble sized particles were obtained from all the segments. The probability plots are further analysed for statistical parameters.

Particle size distribution curves of Segment 4 indicates four distinct sub-populations, two are well sorted and two poorly sorted (Fig. 3a), transported in different modes. The curve between $-11 \phi$ and $-6.5 \phi$ represents particles probably transported by rolling and creeping. The curve between $-6.5 \phi$ and -4 phi $\phi$ represents saltation sub-population. The curve between $-4 \phi$ and $+4 \phi$ indicates sub-population transported in intermittent suspension. The curve at $>4 \phi$ represents suspension transport (wash load).

Particle size distribution plots of Segment 3, Segment 2 and Segment 1 indicate three distinct subpopulations of which coarser (travelled as rolling and creeping) and finer (travelled as suspension) subpopulations are more well sorted while intermediate (saltating) sub-populations are poorly sorted (Fig.
$3 b, c$ and d). The plot of Segment 2 although shows four segments, the intermediate poorly sorted segments are almost similar in transport mode. The particles size distributions of bedmaterial sediments indicate involvement of traction and suspension modes of transport.

\section{Statistical measures of size distribution}

The statistical parameters are listed in Table 2. $D_{\max }$ values (the coarsest particle) were obtained by extrapolating the curve representing coarse subpopulation. $\mathrm{D}_{\max }$ is two to three times higher in substrate of Segment 4 compared to other segments. Median particle size $\left(\mathrm{D}_{50}\right)$ is high in Segment 4 and Segment 1, whereas it is least in Segment 2. The high $\mathrm{D}_{50}$ in the former is due to nearness of source rocks and in the latter can be due to contribution by the fifth order Mahadev Khola. When overall populations of the each of the samples are considered, the samples show very poor sorting according to the sorting categories of Folk and Ward (1957). Sediments of both Segments 1 and 4 are very finely skewed while those of Segment 2 is coarsely skewed and Segment 3 is finely skewed. Median size and skewness parameters of Segment 2 are anomalous and are probably due to excavation of sediments upstream 
Table 2: Percentiles and statistical parameters of size distribution of surface sediment in the Bishnumati River

\begin{tabular}{|c|c|c|c|c|}
\hline & Segment 4 & Segment 3 & Segment 2 & Segment 1 \\
\hline$\overline{D m a x}, \phi$ & -18.3 & -7.5 & -6.5 & -7.15 \\
\hline $\mathrm{D}_{5}, \phi$ & -7.1 & -5.75 & -5.45 & -5.95 \\
\hline $\mathrm{D}_{16}, \phi$ & -5.9 & -4.95 & -4.95 & -5.4 \\
\hline $\mathrm{D}_{25}, \phi$ & -5.5 & -4.55 & -4.8 & -5.2 \\
\hline $\mathrm{D}_{50}, \phi$ & $-4.8(27.86 \mathrm{~mm})$ & $-1.9(3.73 \mathrm{~mm})$ & $0.2(0.871 \mathrm{~mm})$ & $-4.65(25.11 \mathrm{~mm})$ \\
\hline $\mathrm{D}_{75}, \phi$ & -4.1 & 1 & 3.9 & 4 \\
\hline $\mathrm{D}_{84}, \phi$ & -2.8 & 2.5 & 4.05 & 4.15 \\
\hline $\mathrm{D}_{95}, \phi$ & 2.6 & 4.22 & 4.35 & 4.4 \\
\hline Mean, $\mathrm{M}_{\mathrm{Z}},(\phi)$ & 2.63 & 3.12 & 2.93 & 4.73 \\
\hline Median, $\mathrm{D}_{50},(\phi)$ & -4.8 & 1.9 & -0.2 & 4.65 \\
\hline Sorting, $\sigma_{\mathrm{I}},(\phi)$ & 2.24 VPS & 3.37 VPS & 3.73 VPS & VPS \\
\hline Skewness, $\mathrm{SK}_{\mathrm{I}}$ & $0.41 \mathrm{VFS}$ & $0.20 \mathrm{FS}$ & $-0.15 \mathrm{CS}$ & VFS \\
\hline Graphic Kurtosis, $\mathrm{K}_{\mathrm{G}}$ & 2.84 VLK & 0.74 PK & $0.46 \mathrm{VPK}$ & $0.46 \mathrm{VPK}$ \\
\hline
\end{tabular}

of this segment and human modification of channel. Considering the contrast of dominant grain size against the background, this contrast is high for the sediments of Segment 4 (very leptokurtic), low for sediments of Segment 3 (platy kurtic) and very low for Sediments of segments 1 and 3 (very platykurtic).

The overall grain size-grade of the riverbed materials of the Bishnumati River falls on gravel
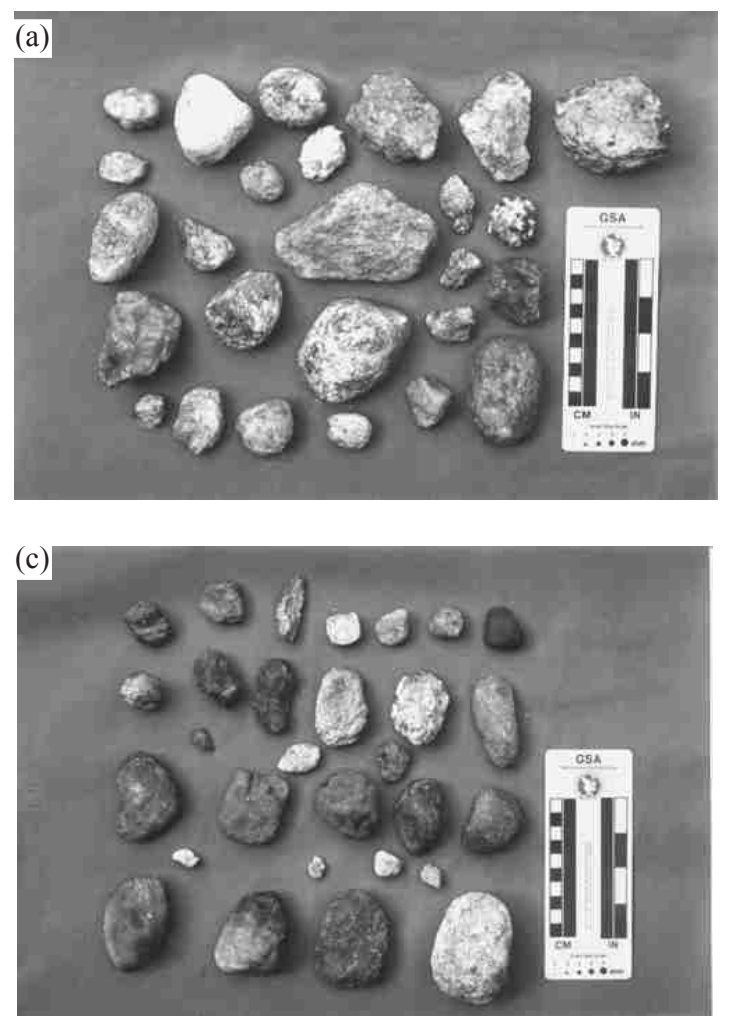

category. More specifically,i.e., considering gravel $(\mathrm{G})$, sand (S) and mud (M) components, the riverbed material of Segment 4 is Gravel $(88 \% \mathrm{G}, 7 \% \mathrm{~S}, 5 \% \mathrm{M})$, Segment 3 is muddy sandy Gravel $(58 \% \mathrm{G}, 34 \% \mathrm{~S}$, $8 \% \mathrm{M})$, Segment 2 is muddy sandy Gravel $(40 \% \mathrm{G}$, $38 \% \mathrm{~S}, 22 \% \mathrm{M})$, and Segment 1 is muddy Gravel $(66 \% \mathrm{G}, 6 \% \mathrm{~S}, 28 \% \mathrm{M})$. The results show that the gravelly bedmaterials progressively become richer in fines from upstream to downstream reaches.
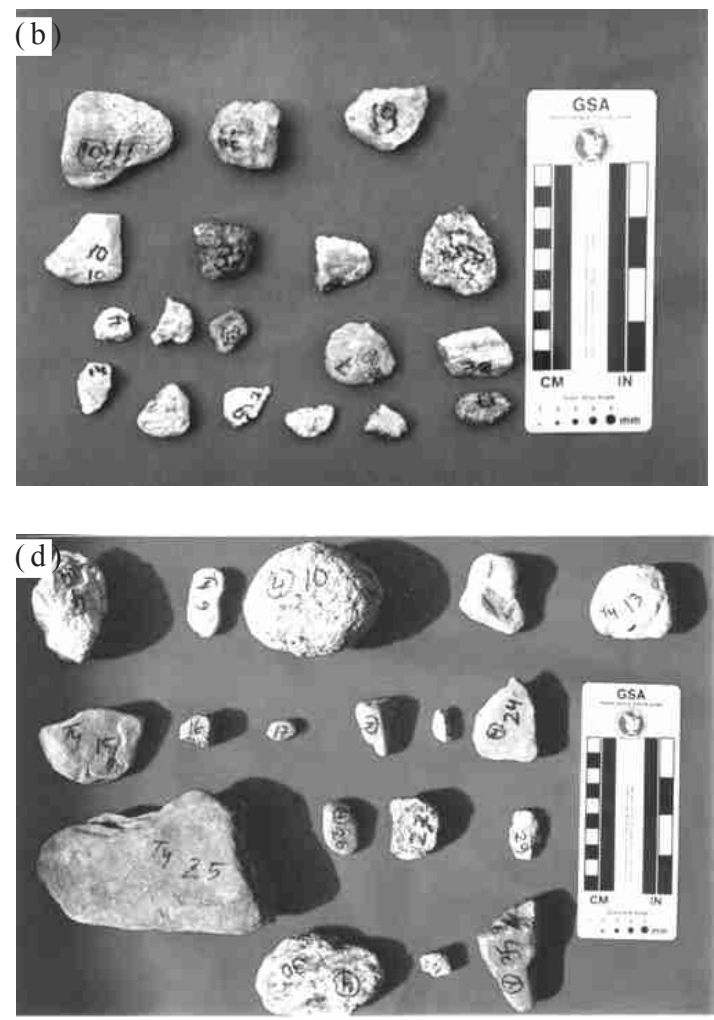

Fig. 4 Photographs showing some gravels from the riverbeds of the Bishnumati River. (a) Segment 4, (b) Segment 3, (c) Segment 2, and (d) Segment 1 


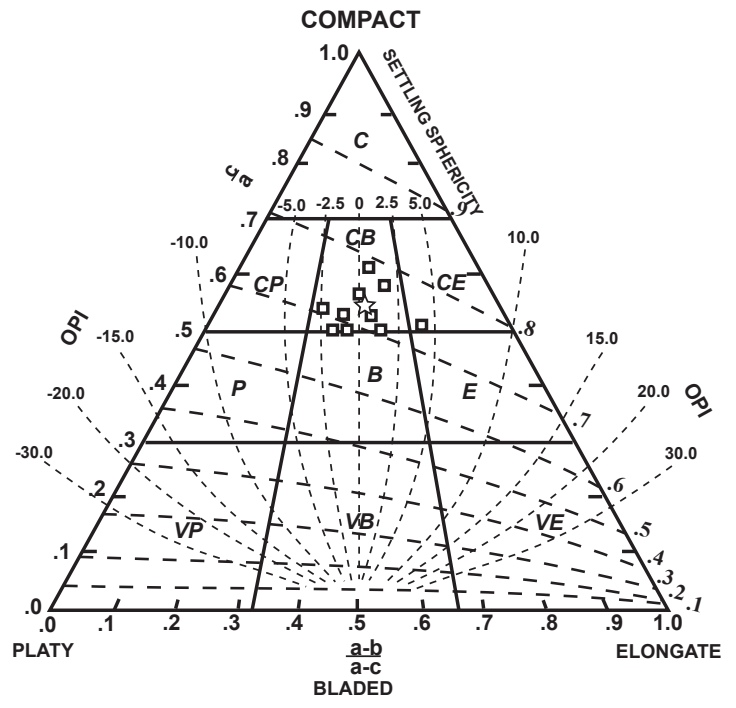

(a)

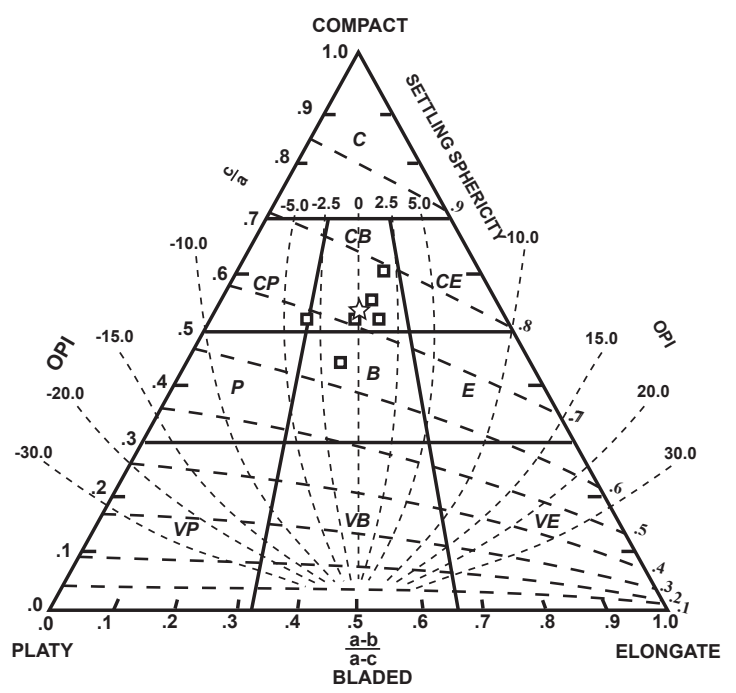

(c)

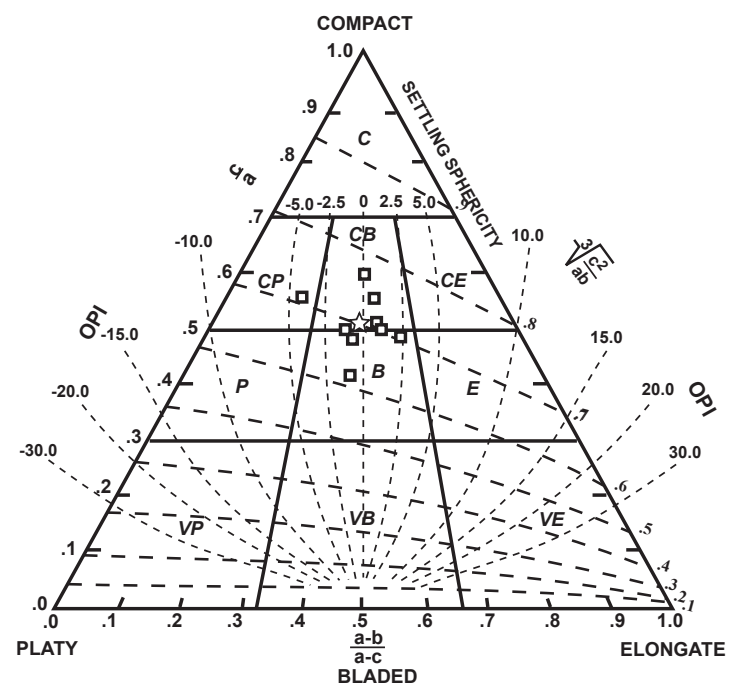

(b)

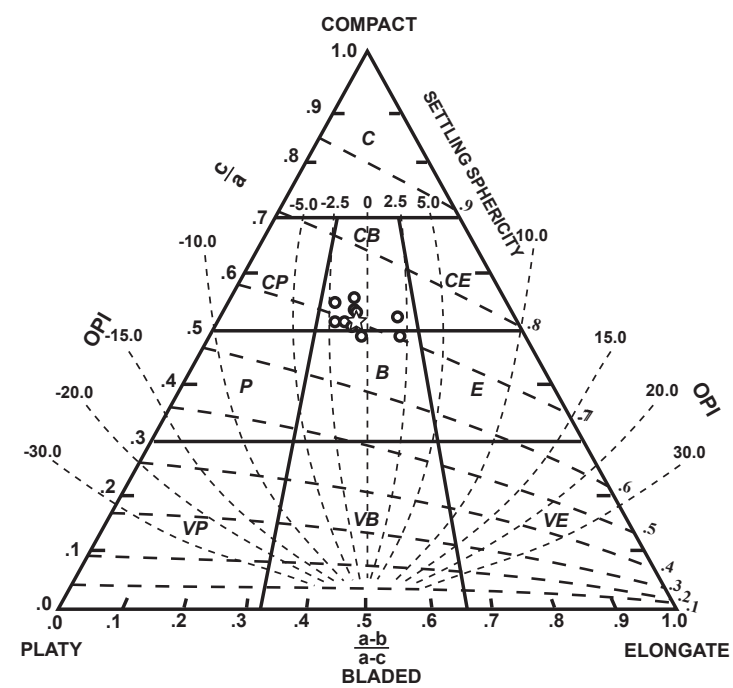

(d)

Fig. 5 Form diagrams indicating plots of axial ratios of gravel from (a) Segment 4, (b) Segment 3, (c) Segment 2, and (d) Segment $1 ; \mathrm{C}=$ compact, $\mathrm{CP}=$ compact platy, $\mathrm{CB}=$ compact bladed, $\mathrm{CE}=$ compact elongate, $\mathrm{P}=$ platy, $\mathrm{B}=$ bladed, $\mathrm{E}=$ elongate, $\mathrm{VP}=$ very platy, $\mathrm{VB}=$ very bladed, and $\mathrm{VE}=$ very elongate

\section{Shape analysis of gravel}

Photographs of some gravels are shown in Fig. 4 to exhibit shapes. Means of all parameters for gravel in each of the segments have been tabulated (Table 3). Axial ratios (c/a and (a-b)/(a-c)) were plotted on Sneed and Folk's (1958) diagram to compare forms (Fig. 5). Plots in triangular form diagrams indicate that majority of the gravel are compact bladed and few bladed and compact platy. All the means of gravel data plot on compact bladed field of the diagram.
Average settling sphericity $\left(\Psi_{\mathrm{p}}\right)$ lies within 0.6 and 0.8 and average settling sphericity values are

Table 3: Shape parameters of riverbed gravels

\begin{tabular}{lccccc}
\hline $\begin{array}{l}\text { Stream } \\
\text { segment }\end{array}$ & c/a & $\begin{array}{c}\text { a-b/a-c } \\
\text { Form factor }\end{array}$ & OPI & $\Psi_{\mathrm{p}}$ & $\rho$ \\
\hline Segment 4 & 0.54 & 0.51 & 0.06 & 0.71 & 2.47 \\
Segment 3 & 0.51 & 0.49 & -0.24 & 0.70 & 2.82 \\
Segment 2 & 0.53 & 0.50 & 0.13 & 0.71 & 2.50 \\
Segment 1 & 0.52 & 0.47 & -0.50 & 0.70 & 3.05 \\
\hline
\end{tabular}

OPI $=$ Oblate prolate index $; \Psi_{\mathrm{p}}=$ Settling sphericity; $\rho=$ Roundness 
Table 4: Composition of gravel from the Bishnumati River

\begin{tabular}{|c|c|c|c|c|c|c|c|c|c|c|}
\hline \multirow[t]{2}{*}{ Stream segment } & \multicolumn{10}{|c|}{ Composition of gravel-cobble particle (\%) } \\
\hline & Gneiss & Granite & *MQF Agg. & Quartzite & Siltstone & Sandstone & Shale & Limestone & Quartz & Others \\
\hline Segment 4 & 64 & 5 & 29 & - & - & - & - & - & 2 & - \\
\hline Segment 3 & 46.10 & 8.51 & 28.37 & 0.71 & 4.26 & 2.13 & - & - & 9.93 & - \\
\hline Segment 2 & 42.9 & 10.7 & 39.3 & 0.7 & - & 4.3 & - & - & & 2.1 \\
\hline Segment 1 & 42.2 & 11.1 & 20.1 & 1.0 & 13.6 & 2.0 & 0.5 & 3.0 & 3.5 & 3.0 \\
\hline
\end{tabular}

$0.71,0.70,0.71$ and 0.71 , respectively obtained from gravel of Segment 4, Segment 3, Segment 2 and Segment 1. Flatness ratio (c/a) ranges from 0.51 to 0.54 . Considering flatness ratio and settling sphericity, the gravels exhibit characters of the fluvial gravels and plot above the limits of Stratten (1974). OPI data show that clasts from Segment 1 are more oblate than those from other segments. This is probably due to increased abundance of sedimentary gravel. Therefore, form of gravel from the Bishnumati River is not so diverse and is abundantly compact bladed. Settling sphericity decreases towards Segment 1 and becomes more oblate (negative values of OPI) than prolate.

Average roundness $(\rho)$ of gravel are $2.47,2.82$, 2.5, and 3.05 in Segment 4, Segment 3, Segment 2 and Segment 1, respectively. Roundness of gravel develops from subangular to subrounded due course of transport. However, abundance of subrounded gravel in Segment 1 can be due to relatively soft and weathered nature of the meta-sedimentary gravel.

\subsection{Gravel composition}

Gravel sized particles obtained in Wolman's pebble count were observed for composition. Majority of the gravel is composed of gneissic rock fragments, followed by mica-quartz-feldspar aggregates, granites, sedimentary and other clasts (Table 4 and Fig. 6). Composition of gravel from Segment 4 is limited to gneissic and granitic composition, whereas composition of gravel from Segment 1 is more diverse compared to other segments (Fig. 6). Segment 1 contains clasts from the Sheopuri Injection Gneiss Zone as well as the Phulchoki Group. Segments 2 and 3 contains majorly the gravels from the Sheopuri Injection Gneiss Zone. But there are also few sedimentary clasts (siltstone and sandstone in Segment 3, and sandstone in Segment 2). These sedimentary clasts were probably supplied by reworking from the fans or fluvio-deltaic deposits containing the clasts of the Phulchoki Group of rocks. Such clasts in these deposits, if present, probably explain different drainage condition from the existing one in the area.

Proportion of sedimentary gravel increases downstream (in Segment 1) most probably due to derivation from the Mahadev Khola and the Bhaucha Khusi sourced to the Phulchoki Group of rocks.
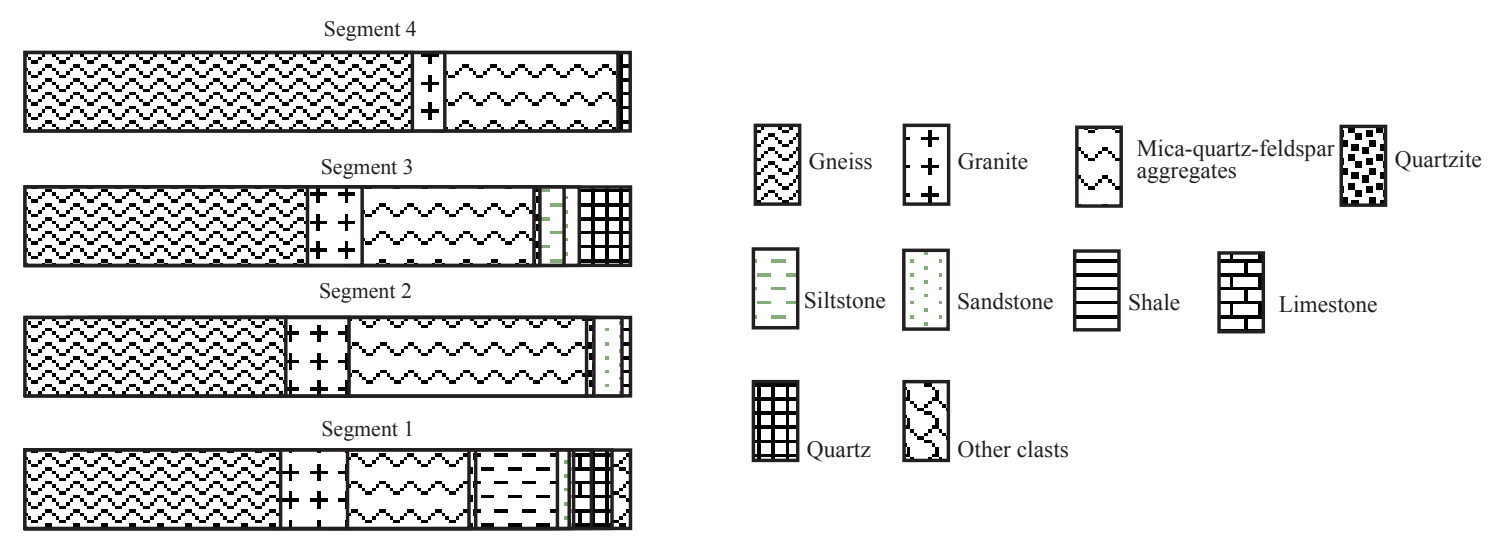

Fig. 6 Representation of composition of gravel from Segment 4, Segment 3, Segment 2 and Segment 1 of the Bishnumati River 


\section{CONCLUSIONS}

The riverbed materials are the gravel-grade sediments. From upstream to downstream, Gravel is accompanied with sand and mud and becomes muddy sandy Gravel and finally muddy Gravel. Size distributions of the sediment exhibit distinct modes of transport with saltation load being poorly sorted. The overall distribution in each case is very poorly sorted.

Form indices show that the gravels plot on compact bladed field. OPI data indicates that the gravels from Segment 1 are more oblate compared to the other segments probably due to increasing abundance of the sedimentary clasts. Gravels have high settling sphericity (0.6-0.8) and are subrounded to rounded although there exist some angular to well rounded gravels. Roundness slightly enhances in downstream segment. The well rounded gravels are supposed to be derived from the older gravel storage.

From overall shape analysis, it is inferred that there is no remarkable downstream variation of shape parameters perhaps because of short distance of transport, insufficient abrasion, greater durability of majority of the clasts, or rapid transport of gravels during floods. High sphericity and compact bladed shape are due to inherent properties of gravel, i.e., gneissic and granitic sources, from which these gravels were derived. The initial shape of gravel perhaps depends on the nature with which the breaking of rocks into rock fragments occurs. Bladed and compact platy fragments showing subrounded curvatures are correlated to siltstone, shale, sandstone, etc., whereas compact bladed and high sphericity gravels are correlated to gneiss and granite.

Gneissic and granitic gravels diminish while sedimentary gravels increase from upstream to downstream segments of the river because of more inputs from the sedimentary source rocks towards downstream segments. Presence of sedimentary gravels in the Segments 2 and 3 is remarkable and the sedimentary gravels in these segments have been perhaps supplied from the terrace deposits lying upstream because the area lying upstream of such deposits at present is devoid of sedimentary rocks of the Phulchoki Group. Presence of such sedimentary gravels even in these terrace deposits is important as it suggests peleo-drainage system, and tectonic conditions different from the present situation.

\section{ACKNOWLEDGEMENT}

Author is thankful to Human and Geoscience Group, Japan and A. Iwata for the support.

\section{REFERENCES}

Adhikari, B. and Tamrakar, N.K., 2006. Bank instability and erosion problems in Bishnumati River, Kathmandu, Nepal. Proceeding of Fifth Asian Regional Conference on Engineering Geology for Major Infrastructure Development and Natural Hazard Mitigation 28-30, 2005, J. Nepal Geol. Soc., Spec. Issue, v. 34, pp. 109-116.

Department of Hydrology and Meteorology (DHM), Ministry of Water Resources, HMG Nepal, 1998. Hydrological records of Nepal, Kathmandu, HMG.

Folk, R.L., 1955. Student operator error in determination of roundness, sphericity, and grain size. J. Sed. Petrol., v. 25 , pp. 297-301.

Folk, R.L. and Ward, W.C, 1957. Brazos river bars, a study in significance of grain size parameters. J. Sed. Petrol., v. 27, pp. 3-27.

Ohta, Y., 1973. Geology of the Nepal Himalayas, In: K., Arita, Y., Ohta, C., Akiba, and Y., Maruo, (eds.), Geology of the Himalayas. Saikon Publ. Co. Ltd., pp. 235-259.

Power, M.C., 1953. A new roundness scale for sedimentary particles. Jour. Sediment. Petrol., v. 23, pp. 117-136.

Rosgen, D.L., 1994. A classification of natural rivers. Catena, v. 22, pp. 169-199. doi:10.1016/03418162(94)90001-9

Sneed, E.J. and Folk, R.L., 1958. Pebbles in the lowedoi:10.1144/gsjgs.137.1.0001r Colorado River, Texas, a study in particle morphogenesis. J. Geol., v. 66, pp. 114-150. doi:10.1086/626490

Stöcklin, J., 1980, Geology of Nepal and its regional frame. J. Geol. Soc. London, v. 137, pp. 1-34. doi:10.1144/gsjgs.137.1.0001

Stratten, T., 1974. Notes on the application of shape parameters to differentiate between beach and river deposits in souther Africa. Trans. Geol. S. Africa, v. 77, pp. 59-64.

Tamrakar, N.K., 2004. Disturbances and Instabilities in the Bishnumati River Corridor, Kathmandu Basin. The JUSAN (Japan University Students Association Nepal), v. 9, issue 16, pp. 7-18.

Wolman, M.G., 1954. A method of sampling coarse riverbed material. Trans. Am. Geophys. Union, v. 35, pp. 951-956. 